\title{
Salinity Tolerance of the Brackish-Water Echinoderm Ophiophragmus filograneus (Ophiuroidea)
}

\author{
R. L. Turner and C. E. Meyer* \\ Department of Biological Sciences, Florida Institute of Technology, Melbourne, Florida 32901, USA
}

\begin{abstract}
Ophiophragmus filograneus is an infaunal brittlestar inhabiting shallow brackish waters of Florida (USA). Its tolerance to salinity changes was studied in the laboratory using burrowing time as an activity criterion. Complete acclimation of burrowing time occurred within $21 \mathrm{~d}$ of continuous acute exposure to salinities of $17-38 \%$. All test animals died within $2 \mathrm{~d}$ at 42 $\%$ and within $19 \mathrm{~d}$ at $10 \%$. Gradual reduction to $8 \%$ from ambient salinity $(25 \%$ during 43 d exposure gave results similar to those of the first experiment. A third experiment gave evidence of acclimatization in a well-established population in the Indian River lagoon, where salinity dropped to $9 \%$ in August 1978. Salinity tolerance of $O$. filograneus allows it to live in the organically rich sediments of Florida bays and lagoons, to which it is restricted, unlike the more stenohaline $O$. wurdemanifrom nearby, marine, sandy habitats. This is the first documented case of an endemic brackish-water echinoderm.
\end{abstract}

\section{INTRODUCTION}

Although much evidence has been accumulated in the past few decades to document the presence of brackish-water populations of at least 22 species of echinoderms (Binyon, 1966), no echinoderm has been found which is endemic to brackish waters (Kinne, 1971; Remane and Schlieper, 1971, pp. 114, 116). The absence of brackish-water species is probably related to the poor ability of echinoderms to osmo- and ionregulate (Binyon, 1972; Prosser, 1973a, b), the lack of an excretory organ (Binyon, 1972), and the biochemical, physiological, reproductive, and morphological effects of reduced salinities on laboratory and field populations (Kowalski, 1955; Kinne, 1971; Remane and Schlieper, 1971)

The echinoderm which has been found in the lowest salinity in the field is the infaunal, deposit-feeding brittlestar Ophiophragmus filograneus, found by Thomas (1961) at $7.7 \%$ in Coot and Whitewater bays, Florida, USA. Based on Thomas' (1961) observation, circumstantial evidence on postmetamorphic growth (Turner, 1974) and reproduction (Stancyk, 1973), and a preliminary knowledge of its distribution, we regarded O. filograneus to be a good candidate for an endemic

\footnotetext{
- Present address: Virginia Institute of Marine Science,
} Gloucester Point, Virginia 23062, USA brackish-water species. Except for a preliminary unpublished study by Stancyk (1970), however, nothing was known about its range of salinity tolerance in the laboratory. Reports of its distribution were scattered, and correlations with salinity of its habitat were few. The purposes of the present paper are to provide experimental evidence for the euryhalinity of $O$. filograneus and to document the restriction of this brittlestar to the brackish bays and lagoons of Florida.

\section{MATERIAL AND METHODS}

Individuals of Ophiophragmus filograneus (Lyman) were collected by shovel and sieve from seagrass (Halodule wrightii) beds in the Indian River lagoon at Melbourne, Florida, USA $\left(28^{\circ} 03.7^{\prime} \mathrm{N}_{i} 80^{\circ} 35.5^{\prime} \mathrm{W}\right)$ in April, June, and September 1978. O. filograneus were held in the laboratory 1-6 d before experimentation to overcome stress potentially imposed by handling and temperature change. Brittlestars were selected for uniformity of size, and those with broken arms or regenerating discs were not used. Clean beach sand from Indialantic, Florida was sieved, and particles of 0.25-1.00 mm diameter were used to provide a standardized substratum for all experiments. Choice of particle sizes was based on the determination by Mur- 
doch (1976) of optimal substrata for burrowing by 0 . filograneus.

Brittlestars were held in $20.3-\mathrm{cm}$ diameter glass bowls with $1-2 \mathrm{~cm}$ of beach sand covered with water to a depth of $3-4 \mathrm{~cm}$. Except during burrowing trials, they were kept in the habitation bowls under reduced light intensity. Water was aerated continuously and changed every other day. The number of individuals per bowl did not exceed six $\left(185 \mathrm{~m}^{-2}\right.$; density in the field was $290 \mathrm{ml}^{-2}$ ). Test salinities were prepared with combinations of ocean water, lagoon water, deionized water, and artificial sea salts. Field and test salinities were measured with an American Optical Corporation refractometer (Model 10419). Test bowls for burrowing trials contained $2-5 \mathrm{~cm}$ of beach sand and water to a depth of $1-2 \mathrm{~cm}$. The burrowing response was used to evaluate the functional well-being of control and experimental animals. Burrowing was timed from the start of sand movement by podia to the disappearance of the disc into the sand. The criterion for death was the lack of podial response to touch.

Three experiments were run to test the effect of salinity on burrowing time. In the first experiment, eight groups of brittlestars were subjected to acute exposure to salinities of $42,38,33,27,21$ (ambient), 17 , 13 , or $10 \%$ for up to $21 \mathrm{~d}$. Burrowing times of the 6 individuals in each group were measured at ambient salinity prior to exposure and daily thereafter at the test salinity. Individuals that did not burrow within 7 min were assigned a time of $420 \mathrm{~s}$. Mean time and standard deviation were calculated for each group in which all brittlestars burrowed within $420 \mathrm{~s}$ on a given day; otherwise, the median burrowing time was calculated.

In the second experiment, 10 individuals were exposed to stepwise reduction of salinity $(25,21,17,13$, 10 , and $8 \%$, and 10 were held at ambient salinity (25 $\%$ o). Burrowing times were measured every $2 \mathrm{~d}$. Salinity in the experimental bowls was reduced after the burrowing trial every sixth day, except for the 9-d exposure to $10 \%$ Brittlestars that did not burrow within 25 min were assigned a time of $1500 \mathrm{~s}$. Mean and median times were calculated as described above.

A third experiment was made after a natural reduction in salinity of the Indian River lagoon occurred between late July and late September 1978. (Abiotic factors other than salinity were not monitored in the field.) The purpose of this experiment was to test for acclimatization of burrowing time. The acclimatization experiment was conducted similarly to the first. The control group was held at ambient salinity $(17 \% 0)$, and each of three experimental groups was exposed to 14 , 11 , or $8 \%$.

Ambient water temperatures at the start of the three experiments were 24,35 , and $29{ }^{\circ} \mathrm{C}$, respectively.
Laboratory temperatures were measured at least every other day during the experiments; means and standard deviations were $23^{\circ} \mathrm{C} \pm 2 \mathrm{C}^{\circ}, 25^{\circ} \mathrm{C} \pm 2 \mathrm{C}^{\circ}$, and $24^{\circ} \mathrm{C}$ $\pm 1 \mathrm{C}^{\circ}$, respectively. Ambient, summer, water temperatures in the lagoon range as much as $6 \mathrm{C}^{\circ}$ diurnally (Thomas, 1974).

\section{RESULTS}

Ophiophragmus filograneus tolerates acute exposure to a wide range of salinities. Initial burrowing times did not differ statistically ( $F=1.37 ; P>0.05)$ among the eight groups, and burrowing times were similar among groups exposed to salinities of $17-38 \%$ after 21 d (Fig. 1b-f). At $42 \%$, no brittlestars burrowed within $420 \mathrm{~s}$ after $1 \mathrm{~d}$, and all were dead by the end of the second day (Fig. 1a). Individuals exposed to $38 \%$ did not burrow for the first $2 \mathrm{~d}$, but they showed gradual acclimation during the subsequent $19 \mathrm{~d}$ (Fig. 1b). All brittlestars at $38 \%$, however, autotomized their discs after several days' exposure, and one individual died by Day 9. At 17-33\% (Fig. 1c-f), burrowing times were somewhat longer and more variable in individuals exposed to salinities above and below

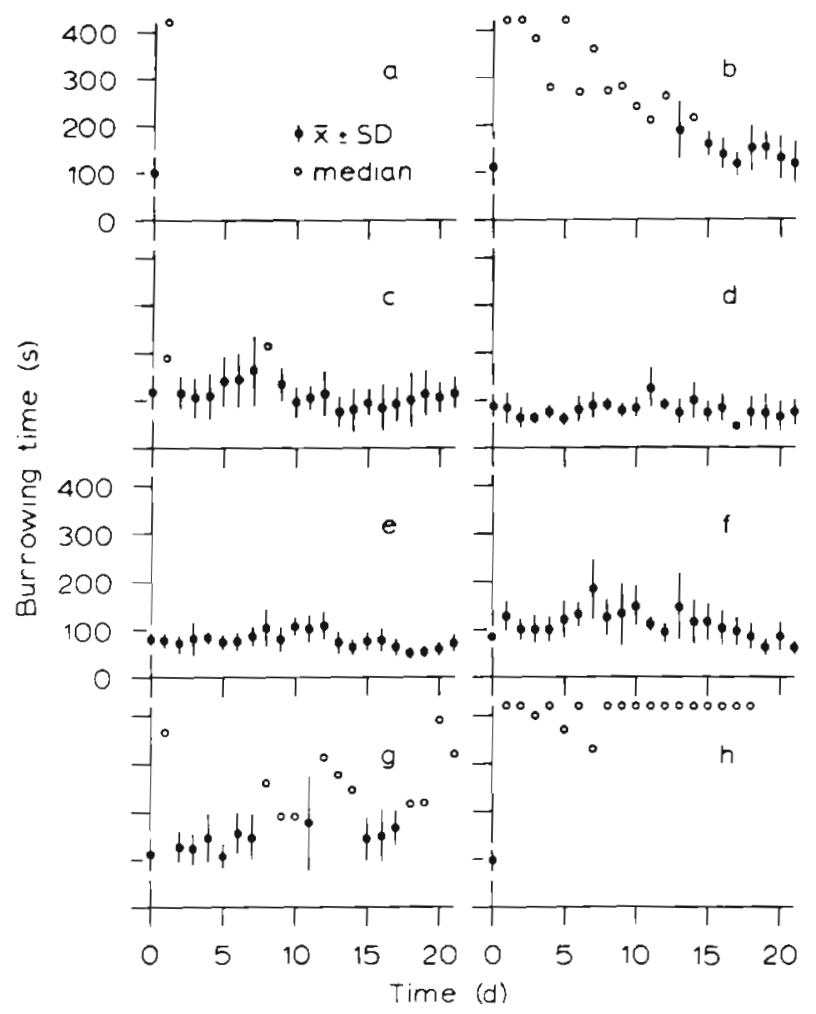

Fig. 1 Ophiophragmus filograneus. Tolerance to prolonged acute exposure to elevated and reduced salinities a: $42 \%$; $38 \%$ c: $33 \%$ i d: $27 \%$ e: $21 \%$ (ambient); f: $17 \% 0 ; \mathrm{g}$ $13 \%$ h: $10 \%$ 


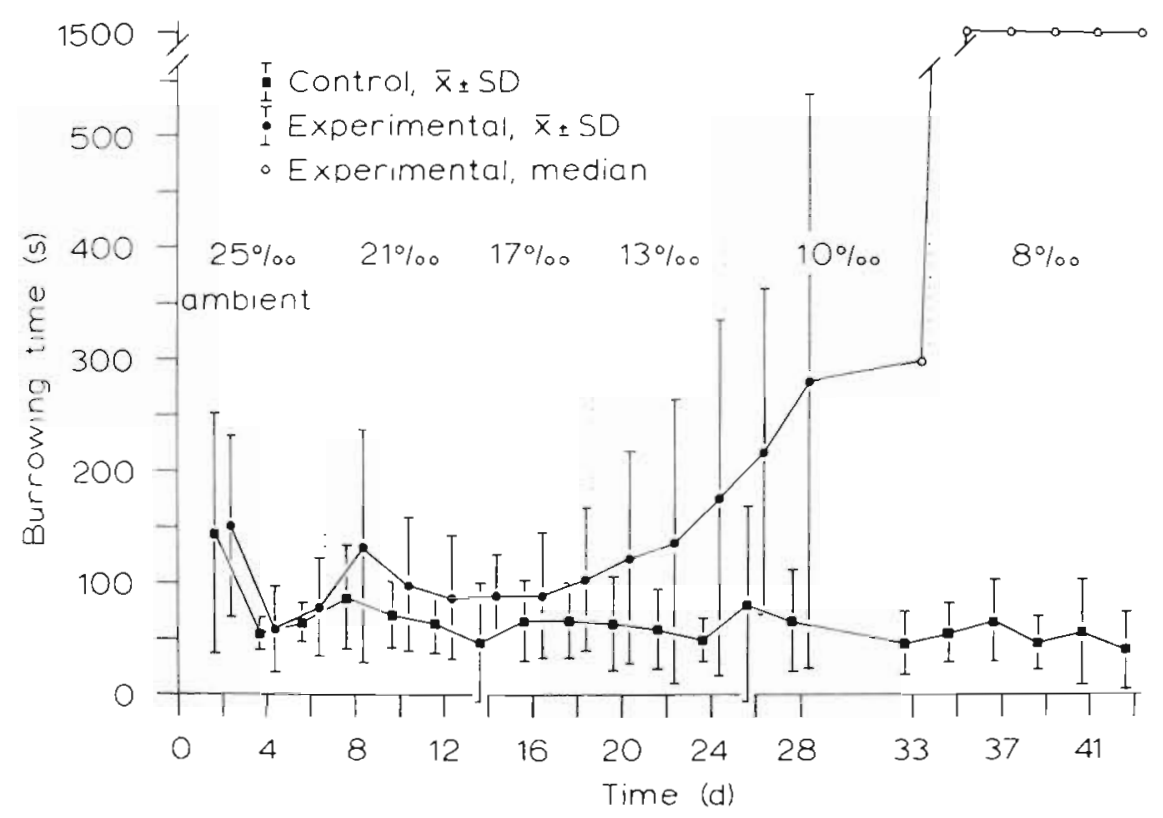

Fig. 2. Ophiophragmus filograneus. Tolerance to gradual exposure to reduced salinities

ambient salinity $(21 \%)$. One individual in the group exposed to $33 \%$ did not burrow on Days 1 and 8 . In contrast to the acclimation which occurred at $38 \%$, burrowing times and the number of non-burrowing individuals at $13 \%$ increased during the experiment (Fig. 1g). Few brittlestars in the $10 \%$ group burrowed within $420 \mathrm{~s}$; all individuals autotomized their discs by Day 14 and died by Day 19.

Gradual exposure to reduced salinities gave results similar to those of acute exposure During the 6-d control period, burrowing times of control and experimental groups were similar (Fig. 2). Burrowing times of the control group remained short during the remaining $37 \mathrm{~d}$. At 21 and $17 \%$, burrowing times of the experimental group were slightly longer and more variable than those of the control group. During exposure to 13 and $10 \%$, burrowing times increased rapidly and were highly variable. One brittlestar did not burrow on Day 33 at $10 \%$, and few (0-4) burrowed within $1500 \mathrm{~s}$ at $8 \%$. Four individuals died on Day 41 , and three on Day 43 when the experiment was terminated. Brittlestars did not undergo autotomy of arms and discs until exposure to a salinity of $8 \%$.

Salinity in the field was above $20 \%$ between April and late July 1978, after which the salinity decreased to $9 \%$ by late August. Salinity increased to $17 \%$ in early September, at which point it remained until the third experiment was begun in late September. Salinity of the interstitial water also was $17 \%$ in September. In the acclimatization experiment (Fig. 3), mean burrowing times of the control group $(17 \%)$ were similar to those of the control group $(21 \%)$ of the first experiment. Individual burrowing times were, however, more variable, and one individual did not burrow on Days 19-21. Burrowing times were slightly longer at $14 \%$ than at $17 \%$, and one brittlestar did not burrow on several days. Burrowing times usually exceeded $200 \mathrm{~s}$ in the group held at $11 \%$; one individual did not burrow on many days, and one or two others did not burrow on Days 1-8. During exposure to salinities of 14 and $11 \%$ (Fig. 3b, c), burrowing times and the number of non-burrowing animals did not increase as they did at $13 \%$ in the first experiment (Fig. $1 \mathrm{~g}$ ) and at 13 and $10 \%$ in the second experiment (Fig. 2). No brittlestars burrowed after exposure to $8 \%$

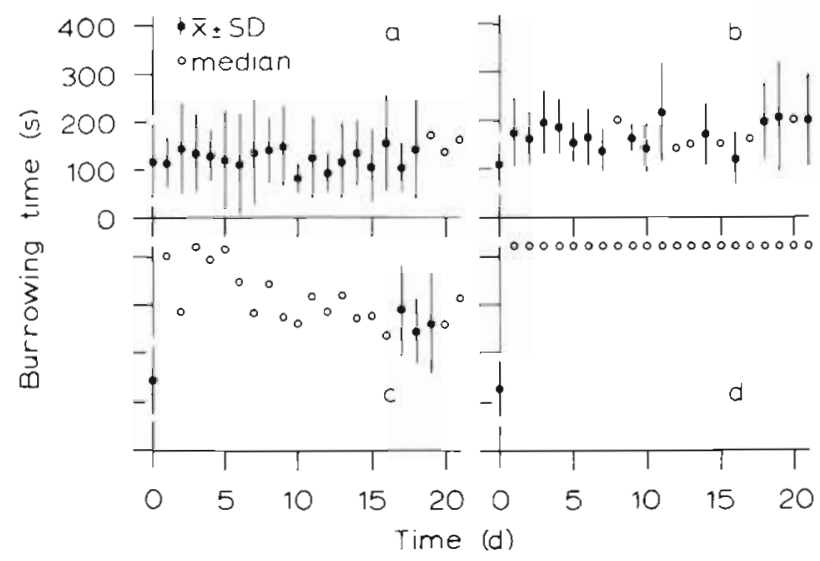

Fig. 3. Ophiophragmus filograneus. Tolerance to prolonged acute exposure to reduced salinities following natural reduction to $9 \%$ in the field. a: $17 \%$ (ambient); b: $14 \%$; c: $11 \%$ d: $8 \%$ 
salinity (Fig. 3d); all individuals lived to Day 13, but only one test animal was alive after Day 16. Autotomy occurred only in brittlestars held at $8 \%$.

\section{DISCUSSION AND CONCLUSIONS}

Activity rates of the whole organism have been used as criteria of well being for individuals subjected to experimental and natural physiological stress. The rationale for using activity rates is that the whole organism functions within narrower environmental limits than do its component organs, cells, and enzymes (e. g. Prosser, 1973c); and only within these limits can ecologically important and highly coordinated processes such as defense, feeding, and orientation occur (Lawrence, 1975). The most widely used criterion for echinoderms has been the ability of an inverted animal to right itself (asteroids: Loosanoff, 1945; Kowalski, 1955; Ellington and Lawrence, 1974; echinoids: Giese and Farmanfarmaian, 1963; Lawrence, 1973, 1975; ophiuroids: Orr, 1955; Stancyk and Shaffer, 1977). Although righting time is an ecologically relevant criterion for epifaunal echinoderms, burrowing time is more appropriate for infaunal amphiurid brittlestars. The burrowing response involves the rapid lateral movement of podia, horizontal coiling and mound construction by the arms, pulling of the disc into the substratum by the arms, and reciprocating rotation of the disc (Woodley, 1975; Murdoch, 1976; R. L. Turner and C. E. Meyer, personal observation). Moreover, the podia are used for feeding and burrow maintenance, and the arms for generation of respiratory currents (Woodley, 1975); these activities require a level of sensory and motor coordination similar to that necessary for burrowing. Burrowing time does not seem to have been used previously as a criterion of well being in echinoderms under physiological stress.

Burrowing times of Ophiophragmus filograneus from an ambient salinity of $21 \%$ were similar after 21 d acute exposure to salinities of $17-38 \%$. Coma and death occurred at 13 and $42 \%$. Although acclimation of the burrowing response occurred between 17 and 38 $\%$, the lower tolerance limit could not be changed by gradual exposure to reduced salinity in the laboratory. Acclimatization did, however, occur in the field population following prolonged reduction of salinity to as low as $9 \%$. $O$. filograneus from an ambient salinity of $17 \%$ were under stress; but they were able to burrow after $21 \mathrm{~d}$ acute exposure to $11 \%$, and none at $8 \%$ died before Day 14. In a preliminary study, Stancyk (1970) measured recovery of the ability of $O$. filograneus and Ophioderma brevispinum to right at ambient salinity $(30 \%)$ after variable exposure times in experimental salinities. O. filograneus held at $12 \%$ regained the ability to right within $41 \mathrm{~h}$ without being returned to ambient salinity. One individual recovered within $10 \mathrm{~h}$ at ambient salinity after $6 \mathrm{~h}$ exposure to 7.6 $\%$; but five others did not recover from longer exposures. $O$. brevispinum was less tolerant of low salinity, but 10 individuals held at $15 \%$ for $283 \mathrm{~h}$ recovered in ambient salinity.

Only three other ophiuroid species have been studied, and they are less tolerant of reduced salinities under laboratory conditions (Binyon, 1966; Stancyk and Shaffer, 1977). Apparentiy, the upper tolerance limit has not been determined previously for an ophiuroid; Ophiophragmus filograneus recovered from exposure to the highest salinity $(39 \%$ ) used by Stancyk (1970). Laboratory studies of other echinoderms show that most species are less tolerant than $O$. filograneus to prolonged reduction of salinity (Binyon, 1966, 1972; Lawrence, 1975). Some species do tolerate brief (Loosanoff, 1945) or cyclic (Stickle and Ahokas, 1974; Shumway, 1977) exposure. Acclimation of activity rates at reduced salinities has been found in some echinoderms (Binyon, 1972; Ellington and LawIence, 1974). Acclimatization does not seem to have been studied, but Stancyk and Shaffer (1977) described a possible case of genetic adaptation to environmental salinities in estuarine populations of Ophiothrix angulata.

Populations of several echinoderms, especialiy ophiuroids, occur in brackish waters. Information on ambient salinities in which echinoderms are found was reviewed by Binyon (1966, 1972), Kinne (1971), and Remane and Schlieper (1971). Members of wellstudied, brackish-water echinoderm populations differ in several ways from members of marine populations. Kowalski (1955), for example, found Asterias rubens from the Baltic Sea to have a longer righting time, smaller body size, different organic and inorganic composition, later maturation, and lower reproductive capacity than individuals from the North Sea. Some estuarine populations are sterile and are maintained only by recruitment (Kinne, 1971). When the effects of reduced salinities on echinoderms in the laboratory and field are considered, it is understandable that no truly brackish-water echinoderm has been reported (e. g. Remane and Schlieper, 1971).

Ophiophragmus filograneus is, however, endemic to the brackish-water bays and lagoons of Florida in association with the seagrass Halodule (Diplanthera) wrightii. The geographic distribution of $O$. filograneus (Fig. 4) is based on published and unpublished reports, museum field records, loans of preserved specimens, personal communications, and the authors own field records. The distribution of its congener $O$. wurdemani in Florida (Fig. 4) is presented for comparison. 


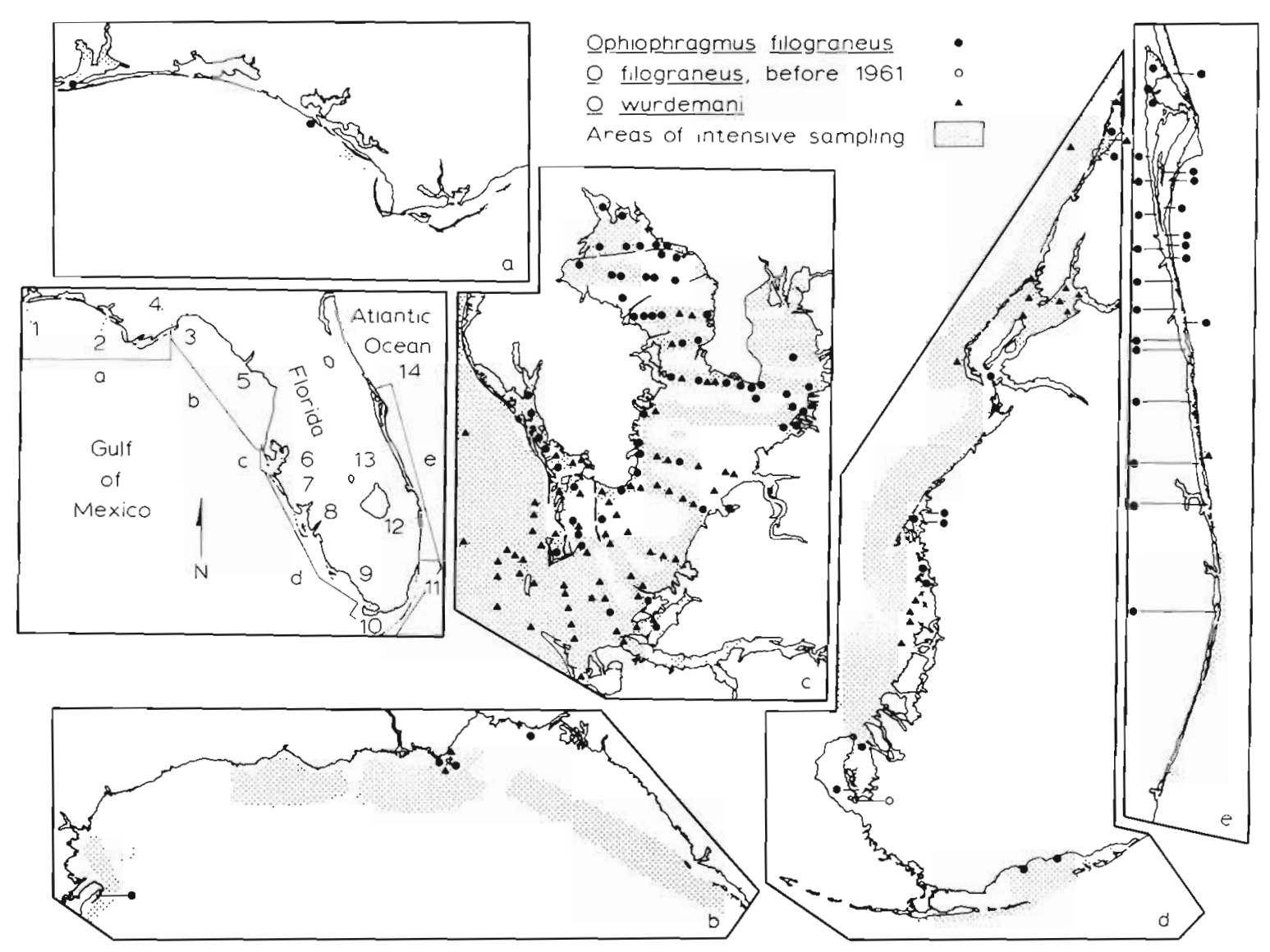

Fig. 4. Ophiophragmus filograneus and $O$ wurdeman. Distrubution in Florida, USA a: western Flonda; b: northeastern Gulf of Mexico; c: Tampa Bay region; d: southwestern Florıda; e: east-central Flonda 1. Pensacola Bay estuarine system; 2: St. Andrew's Bay; 3: Apalachee Bay-St. George's Sound; 4: Allıgator Harbor, 5: Cedar Keys regıon; 6: Tampa Bay estuarıne system; 7: Sarasota Bay; 8: Charlotte Harbor; 9: Whitewater and Coot bays; 10: Florida Bay; 11: Biscayne Bay; 12: Lake Worth; 13: Indian River lagoon; 14: Mosquito Lagoon. Stippling areas sampled intensıvely by dredge, grab, corer, shovel, or other methods which might retrieve infaunal brittlestars. Trawl samples not included. Sources of data given in the text

Ophiophragmus filograneus occurs in several estuaries of western Florida (Fig. 4a, b). Cooley (1978) found it in 1962-1963 at the mouth of the Pensacola Bay estuarine system ( $<<31 \%$ ); but none was found by Olinger et al. (1975) in 1973-1974 in the rest of the estuary, where most seagrass beds gradually died between 1949 and 1974. Thomas (1965) found $O$. filograneus in Alligator Harbor $(S=28-32 \%$; R. W. Menzel, personal communication). Menzel (1971) reported $O$. filograneus from the estuarine Apalachee Bay-St. George's Sound region but gave no station data. O. filograneus occurs in the Cedar Keys region (Stancyk, 1970) and at the mouth of Crystal River (Evink and Green, 1974); these areas are estuarine despite their apparent exposure (Stancyk and Shaffer, 1977). No Ophiophragmus spp. were found at 171 stations sampled by Godcharles and Jaap (1973) in the northeastern Gulf of Mexico $(\mathrm{S}>29 \%$ ). The origin of one $O$. filograneus found on an exposed beach near St. Andrew's Bay by Saloman and Naughton (1977) is in doubt because the individual was collected $2 \mathrm{~d}$ after Hurricane Eloise (1975) passed through the area (C. H. Saloman, personal communication). O. filograneus and O. wurdemani are sympatric in the Apalachee Bay-St. George's Sound (Menzel, 1971) and Cedar Keys (Stancyk, 1970, personal communication) regions.

Extensive faunal and hydrographic surveys of the Tampa Bay region (Fig. 4c) show that $O$. filograneus is confined to brackish waters of all five sub-areas of the estuary (Godcharles, 1971; Bloom et al., 1972; Godcharles and Jaap, 1973; Turner, 1974; Hall and Saloman, 1975; Mahadevan et al., 1977; J. D. Murdoch and J. L. Simon, personal communications). Means and ranges of salinity for the five sub-areas are listed by Simon (1975). O. wurdemani does not penetrate as far into Tampa Bay, generally inhabits deeper, more saline waters, and occurs offshore (Godcharles, 1971; Godcharles and Jaap, 1973; Hall and Saloman, 1975). Along the southwest coast of Florida (Fig. 4d), Ophiophragmus filograneus occurs in the following 
estuaries: Sarasota Bay (Thomas, 1965; Tiffany, 1974), $\mathrm{S}=24-40 \%$ (J. B. Morrill, personal communication); San Carlos and Estero bays near Ft. Meyers (Thomas, 1962, 1965); near Marco Island, $S=19-39 \%$ (Weinstein et al., 1977); Fahka Union Bay, $S=11-29 \%$, and Fahkahatchee Bay, $\mathrm{S}=27-32 \%$ of the Ten Thousand Islands region (Evink, 1975). Its apparent absence from Charlotte Harbor (Godcharles and Jaap, 1973) has been substantiated by our examination of more recently collected ophiuroid material on loan from Environmental Quality Laboratory, Inc. The absence of O. filograneus is unexpected because of the estuarine conditions (Dragovich et al., 1966; Taylor, 1975) and the presence of Halodule wrightij (Godcharles and Jaap, 1973) in Charlotte Harbor. O. wurdemani is sympatric with $O$. filograneus in Sarasota Bay (Tiffany, 1974), and it also occurs in Charlotte Harbor and in the Gulf of Mexico (Thomas, 1962; Godcharles and Jaap, 1973).

At the southern tip of Florida (Fig. 4d), Ophiophragmus filograneus once occurred in large numbers in Coot and Whitewater bays (Tabb and Manning, 1961; Thomas, 1961; Tabb et al., 1962), where mean salinities (and ranges) were $25 \%(6-41 \%$ ) and $19 \%$ $(4-40 \%$ ), respectively (Tabb et al., 1962). The population apparently died before 1961 (Thomas, 1961) along with Halodule wrightii (Tabb et al., 1962). Both the brittlestar and the seagrass were found in Whitewater Bay by Davis and Hilsenbeck (1974) in 1973-1974. O. filograneus has not been collected in nearby Florida Bay, which has a mean annual salinity of $35 \%$ (Tabb et al., 1962).

In Biscayne Bay (Fig. 4d), low salinities occur only along the continental shoreline, where Halodule wrightii is found (Roessler and Beardsley, 1975) and where groundwater seeps upward through the sediment (L. P. Thomas, personal communication). Ophiophragmus filograneus is found near shore (Pearson, 1937; Thomas, 1962) but not in Biscayne Bay proper (McNulty, 1961; McNulty et al., 1962; O'Gower and Wacasey, 1967; L. P. Thomas, personal communication). O. filograneus occurs in Lake Worth (Thomas, 1962) (Fig. 4e), and it is common throughout the Indian River lagoon (Thomas, 1962; Thomas, 1974; Wiederhold, 1976; Grizzle, 1979; D. A. Bruzek, K. D. Levy, J. D. Rice, and R. P. Trocire, personal communications; Harbor Branch Foundation, field records; R. L. Turner, personal observation) in association with extensive beds of $H$. wrightii (Thompson, 1978). The lagoon is brackish (Wiederhold, 1976; Zweck and Adragna, 1976; Grizzle, 1979), although some areas are seasonally hypersaline (Young et al., 1976). The northernmost occurrence of $O$. filograneus to our knowledge is in southern Mosquito Lagoon (D. A. Bruzek, personal communication), although $H$. wrightii extends throu'gh northeastern Florida (Phillips, 1960; Hanlon and Voss, 1975). Several O. wurdemani were collected in the Atlantic Ocean off Hutchinson Island (Florida Department of Natural Resources, field records) (Fig. 4e), but no Ophiophragmus spp. were found at 94 offshore stations sampled by Godcharles and Jaap (1973) (Fig. 4d, e).

The brackish bays and lagoons of Florida are rimmed with mangroves and are vegetated with seagrasses. Both community types produce large quantities of detritus and provide a year-round supply for detrital food chains (Lugo and Snedaker, 1974; Thayer et al., 1975). Ophiophragmus filograneus forms dense, reproductive populations in the seagrass beds (Tabb et al., 1962; Thomas, 1965; Stancyk, 1974; Tumer, 1974, personal observation; Thomas, 1974) and probably feeds on autochthonous detritus as well as the imported detritus from mangals. It is a deposit feeder, whereas $O$. wurdemani is a suspension feeder which lives in grass-free, clean or muddy sands (Thomas, 1961, 1965; Stancyk, 1970). Although the range of salinity tolerance of $O$. filograneus should not restrict it to brackish waters, food requirements might. Euryhalinity, in addition to behavioral, morphological, and developmental adaptations (Stancyk, 1973; Turner, 1974), probably has allowed $O$. filograneus to inhabit successfully a nutritionally rich biotope where few other echinoderms are found.

Acknowledgements. Technical assistance in the field and laboratory was provided by L. J. Ensminger, K. C. Cook, and B. K. Brown, to whom we are grateful. In addition to colleagues whose personal communications are acknowledged in the text, we thank the following for discussion of our results and for suggestion or transmittal of references on hydrography and faunal studies of Florida bays and lagoons: D. K Camp, S. W. Carney, N. R. Cooley, G. E. Davis, E. D. Estevez, G. L. Evink, P. V. Hamilton, C. L. Hunter, J. M. Lawrence, F. J. S. Maturo, R. W Menzel, J. E. Miller, S. A. Rice, C. H. Saloman, J. L. Simon, S. E. Stancyk, and W. J. Tiffany. We also thank T. H. Fraser (Environmental Quality Laboratory, Port Charlotte), W. G. Lyons (Marine Research Laboratory, Florida Department of Natural Resources, St. Petersburg), W. J. Tiffany (Mote Marine Laboratory, Sarasota), and R. W Virnstein (Harbor Branch Foundation, Ft. Pierce) for allowing us to examine specimens and field records in their care. Finally, we are grateful to K. B. Clark, J. H. Dearborn, and L. P. Thomas for commenting on the manuscript. This work was supported in part by National Science Foundation grant SER 77-06567.

\section{LITERATURE CITED}

Binyon, J. (1966). Salinity tolerance and ionic regulation. In: Boolootian, R. A. (ed.) Physiology of Echinodermata. Wiley, New York, pp. 359-377

Binyon, J (1972). Physiology of echinoderms, Pergamon Press, Oxford

Bloom, S. A., Simon, J. L. Hunter, V D. (1972). Animalsediment relations and community analysis of a Florida estuary. Mar Biol. 13: 43-56 
Cooley, N. R. (1978). An inventory of the estuarine fauna in the vicinity of Pensacola, Florida. Fla mar Res. Publ. 31 : $1-119$

Davis, G. E., Hilsenbeck, C. E. (1974). The effects of watershed management on the Shark Slough-Whitewater Bay estuary of Everglades National Park, Florida. United States Department of the Interior, Nationa! Park Service. (Unpublished report)

Dragovich, A., Kelly, J. A., Jr., Finucane, J. H. (1966) Oceanographic observations of Tampa Bay, Charlotte Harbor, Pine Island Sound, Florida, and adjacent waters of the Gulf of Mexico, February 1964 through February 1965 United States Department of the Interior, Fish and Wildlife Service, Data Report 13, 1-73

Ellington, W R., Lawrence, J. M. (1974). Coelomic fluid volume regulation and isosmotic intracellular regulation by Luidia clathrata (Echinodermata: Asteroidea) in response to hyposmotic stress. Biol. Bull. mar, biol. Lab., Woods Hole 146: 20-31

Evink, G. L. (1975). Macrobenthos comparisons in mangrove estuaries. In: Walsh, G. E., Snedaker, S. C., Teas, H. J (eds) Proceedings of the International Symposium on Biol. ogy and Management of Mangroves, Vol. I. Institute of Food and Agricultural Sciences, University of Florida, Gainesville, pp. 256-285

Evink, G., Green, B. (1974). Benthic invertebrate comparisons in two estuaries adjacent to the Crystal River power generation facility. In Snedaker, S. C. (ed.) Crystal River power plant environmental considerations: final report to the Interagency Research Advisory Committee, Vol. III Florida Power Corporation, Miami, pp. 1-87

Giese, A. C., Farmanfarmaian, A. (1963). Resistance of the purple sea urchin to osmotic stress. Biol. Bull. mar. biol Lab., Woods Hole 124: 182-192

Godcharles, M. F. (1971). A study of the effects of a commercial hydraulic clam dredge on benthic communities in estuarine areas. Fla tech. Ser 64:1-51

Godcharles, M. F., Jaap, W. C. (1973). Fauna and flora in hydraulic clam dredge collections from Florida west and southeast coasts. Fla spec. scient. Rep. 40: 1-89

Grizzle, R. E. (1979). A preliminary investigation of the effects of enrichment on the macrobenthos in an east-central Florida lagoon. Fla Scient. 42: 33-42

Hall, J. R., Saloman, C. H. (1975). Distribution and abundance of macroinvertebrate species of six phyla in Tampa Bay, Florida, 1963-64 and 1969. United States Department of Commerce, National Oceanic and Atmospheric Administration, National Marine Fisheries Service, Data Report 100: $1-505$

Hanlon, R., Voss, G. (1975). Guide to the sea grasses of Florida, the Gulf of Mexico and the Caribbean Region, University of Miami Sea Grant Program, Miami

Kinne, O. (1971). Salinity: animals: invertebrates. In: Kinne, O. (ed.), Marine ecology, Vol. I. Environmental factors, Part 2. Wiley, New York, pp. 821-995

Kowalski, R. (1955). Untersuchungen zur Biologie des Seesternes Asterias rubens L. in Brackwasser. Kieler Meeresforsch. 11: 201-213

Lawrence, J. M. (1973). Temperature tolerances of tropical shallow-water echinoids (Echinodermata) at Elat (Red Sea). Israel J. Zool. 22: 143-150

Lawrence, J. M. (1975). The effect of temperature-salinity combinations on the functional well-being of adult Lytechinus variegatus (Lamarck) (Echinodermata, Echinoidea). J. exp. mar. Biol. Ecol. 18: 271-275

Loosanoff, V L. (1945). Effects of sea water of reduced salinities upon starfish, $A$. forbesi, of Long 1sland Sound. Trans. Connecticut Acad. Arts Sci. 36: 813-835

Lugo, A. E., Snedaker, S. C. (1974). The ecology of mangroves. A. Rev. Ecol. Syst. 5: 39-64

Mahadevan, S., Murdoch, J. J. B., Reeves, F. S., Culter, J. K., Lotspeich, R. A., Murdach, J. D. (1977). A study on the effects of thermal discharges on benthic infaunal community structure at Big Bend, Tampa Bay (Florida). In: Garrity, R. D., Tiffany, W. J., Mahadevan, S. (eds) Appendix to Big Bend Station, 316 Demonstration, September, 1977 Tampa Electric Company, Tampa

MCNulty, J. K. (1961). Ecological effects of sewage pollution in Biscayne Bay, Florida: sediments and the distribution of benthic and fouling macro-organisms. Bull. mar. Sci. Gulf Carib. 11: 394-447

McNulty, J. K., Work, R. C., Moore, H. B. (1962). Level sea bottom communities in Biscayne Bay and nelghboring areas. Bull. mar Sci. Gulf Carib. 12: 204-233

Menzel, R. W. (ed.) (1971). Checklist of the marine fauna and flora of the Apalachee Bay and the St. George's Sound area, 3rd ed., Department of Oceanography, Florida State University, Tallahassee

Murdoch, J. D. (1976). The importance of substratum characteristics on the ability to burrow of two species of amphiurid ophiuroid (Echinodermata). M. Sc. thesis, University of South Florida

O'Gower, A. K., Wacasey, J. W. (1967). Animal communities associated with Thalassia, Diplanthera, and sand beds in Biscayne Bay. I. Analysis of communities in relation to water movements. Bull. mar. Sci. 17: 175-210

Olinger, L. W., Rogers, R. G., Fore, P. L., Todd, R. L., Mullins, B. L., Bisterfeld, F. T., Wise, L. A. (1975). Environmental and recovery studies of Escambia Bay and the PensacolaBay system, Florida. United States Environmental Protection Agency, EPA 904 9-76-016

Orr, P. R. (1955). Heat death. I. Time-temperature relationships in marine animals. Physiol. Zool. 28: 290-294

Pearson, J. F. W. (1937). Studies on the life zones of marine waters adjacent to Miami: I. The distribution of the Ophiuroidea. Proc. Fla Acad. Sci. 1. 66-72

Phillips, R. C. (1960). Observations on the ecology and distribution of the Florida seagrasses. Fla prof. Pap. Ser 2: $1-72$

Prosser, C. L. (1973a). Water: osmotic balance; hormonal regulation. In: Prosser, C. L. (ed.), Comparative animal physiology, 3rd ed. W. B. Saunders, Philadelphia, pp. 1-78

Prosser, C. L. (1973b). Inorganic ions. In: Prosser, C. L. (ed.), Comparative animal physiology, 3rd ed. W. B. Saunders, Philadelphia, pp. 79-110

Prosser, C. L. (1973c). Introduction. In: Prosser, C. L. (ed.) Comparative animal physiology, 3rd ed. W. B. Saunders, Philadelphia, pp. xv-xxii

Remane, A., Schlieper, C. (1971). Biology of brackish water, Wiley, New York

Roessler, M. A., Beardsley, G. L. (1975). Biscayne Bay: its environment and problems. Fla Scient. 37: 186-204

Saloman, C. H., Naughton, S. P. (1977). Effect of Hurricane Eloise on the benthic Iauna of Panama City Beach, Florida, USA. Mar. Biol. 42: 357-363

Shumway, S. E. (1977). The effects of fluctuating salinities on four species of asteroid echinoderms. Comp. Biochem. Physiol. 58A: 177-179

Simon. J. L. (1975). Tampa Bay estuarine system-a synopsis. Fla Scient. 37: 217-244

Stancyk, S. E. (1970). Studies on the biology and ecology of ophiuroids at Cedar Key, Florida. M. Sc. thesis, University of Florida 
Stancyk, S. E. (1973). Development of Ophiolepis elegans (Echinodermata: Ophiuroidea) and its implications in the estuarine environment. Mar Biol. 21. 7-12

Stancyk, S. E. (1974). Life history patterns of three estuarine brittlestars (Ophiuroidea) at Cedar Key, Florida. Ph. D. thesis, University of Florida

Stancyk, S. E., Shaffer, P. L. (1977). The salinity tolerance of Ophiothrix angulata (Say) (Echinodermata: Ophiuroidea) in latitudinally separate populations. J. exp. mar Biol. Ecol. 29: 35-43

Stickle, W. B., Ahokas, R. (1974). The effects of tidal fluctuation of salinity on the perivisceral fluid composition of several echinoderms. Comp. Biochem. Physiol. 47A: $469-476$

Tabb, D. C., Dubrow, D. L., Manning, R. B. (1962). The ecology of northern Florida Bay and adjacent estuaries. Fla tech. Ser. 39: 1-81

Tabb, D. C., Manning, R. B. (1961). A checklist of the flora and fauna of northern Florida Bay and adjacent brackish waters of the Florida mainland collected during the period July, 1957 through September, 1960. Bull. mar. Sci. Gulf Carib. 11: 552-649

Taylor, J. L. (1975). The Charlotte Harbor estuarine system. Fla Scient. 37: 205-216

Thayer, G. W., Wolfe, D. A., Williams, R. B. (1975). The impact of man on seagrass systems. Am. Scient. 63: 288-296

Thomas, J R. (1974). Benthic species diversity and environmental stability in the northern Indian River, Florida. $M$. Sc. thesis, Florida Institute of Technology

Thomas, L. P. (1961). Distribution and salinity tolerance in the amphjurid brittlestar, Ophiophragmus filograneus (Lyman, 1875). Bull. mar. Sci. Gulf Carib. 11: 158-160

Thomas, L. P. (1962). The shallow water amphiurid brittle stars (Echinodermata, Ophiuroidea) of Florida. Bull mar. Sci. Gulf Carib. 12: 623-694

Thomas, L. P. (1965). A monograph of the amphiurid brittlestars of the western Atlantic. Ph. D. thesis, University of Miami

Thompsan, M. J. (1978). Species composition and distribution of seagrass beds in the Indian River lagoon, Florida. Fla Scient. 41. 90-96

Tiffany, W J. (1974). Checklist of benthic invertebrate communities in Sarasota Bay with special reference to water quality indicator species. Flower Gardens Ocean Research Center, University of Texas, Galveston, Contribution No. 2, $1-123$

Turner, R. L. (1974). Post-metamorphic growth of the arms in Ophiophragmus filograneus (Echinodermata: Ophiuroidea) from Tampa Bay, Florida (USA). Mar. Biol. 24: 273-277

Weinstein, M. P., Courtney, C. M., Kinch, J. C. (1977). The Marco Island estuary: a summary of physicochemical and biological parameters. Fla Scient. 40: 97-124

Wiederhold, C. N. (1976). Annual cycles of macrofaunal benthic invertebrates in the northern Indian River. Florida. M. Sc. thesis, Florida Institute of Technology

Woodley, J. D. (1975). The behaviour of some amphiurid brittle-stars. J. exp. mar. Biol. Ecol. 18: 29-46

Young, D. K., Buzas, M. A., Young, M. W. (1976). Species densities of macrobenthos associated with seagrass: a field experimental study of predation. J. mar. Res. 34: $577-592$

Zweck, O. v., Adragna, G. (1976). Physical oceanographic studies of the Indian River region. In: Young, D. K. (ed.) Indian River coastal zone study, 1975-1976, Annual report, Vol. I. Harbor Branch Consortium, Fort Pierce, Florida, pp. 20-24 